\title{
Correction to: Managed Wetlands Can Benefit Juvenile Chinook Salmon in a Tidal Marsh
}

\author{
Nicole M. Aha ${ }^{1,2} \cdot$ Peter B. Moyle ${ }^{1,2} \cdot$ Nann A. Fangue ${ }^{2} \cdot$ Andrew L. Rypel $^{1,2} \cdot$ John R. Durand ${ }^{1,2}$
}

Published online: 10 October 2021

(c) The Author(s) 2021

\section{Correction to: Estuaries and Coasts (2021) 44:1440-1453 \\ https://doi.org/10.1007/s12237-020-00880-4}

In the original online version of this article, there were some errors in the values in Table 7. The original article was corrected.

The original article can be found online at https://doi.org/10.1007/ s12237-020-00880-4.

Nicole M. Aha

nmaha@ucdavis.edu

1 Center for Watershed Sciences, University of California, Davis, Davis, CA, USA

2 Department of Wildlife, Fish \& Conservation Biology, University of California, Davis, Davis, CA, USA 